\title{
Site of action of a gonococcal growth inhibitor produced by Staphylococcus haemolyticus
}

\author{
M. FRENETTE, R. BEAUDET*, J.-G. BISAILLON and V. PORTELANCE
}

Centre de recherche en Microbiologie appliquée, Institut Armand-Frappier, Université du Québec, Ville de Laval, Québec, H7N 4Z3, Canada

\begin{abstract}
Summary. The inhibitory substance produced by Staphylococcus haemolyticus strain no. 7 acts on growing as well as resting gonococcal cells, as shown by reductions in viable counts. The optical density of these cell suspensions was only slightly reduced. The inhibitor caused lysis of gonococcal spheroplasts at $24^{\circ} \mathrm{C}$ and $37^{\circ} \mathrm{C}$, but was much less active at $4^{\circ} \mathrm{C}$. Acting on intact gonococcal cells, the inhibitor caused a temperature-dependent release of radioactive cytoplasmic material. Electronmicroscopy showed that treated suspensions contained ghost cells with the cell envelope relatively intact. Our results suggest that the inhibitor may act on the cytoplasmic membrane of the gonococcal cell causing cytoplasmic leakage and, eventually, death.
\end{abstract}

\section{Introduction}

In-vitro inhibition of Neisseria gonorrhoeae by micro-organisms present in the urogenital flora has been reported by several workers (Kraus and Ellison, 1974; Kraus et al., 1976; Kaye and Levison, 1977; Ingraham, 1978; Morin et al., 1980; Bisaillon et al., 1981b). Kraus and Ellison (1974) have suggested that such inhibition may play a role in host resistance to gonorrhoea. Substances responsible for gonococcal inhibition have been isolated and purified (Dajani et al., 1976; Morse et al., 1976; Rogolski and Wiley, 1977; Simpson and Davis, 1979; Beaudet et al., 1982; Dubreuil et al., 1984; Morin et al., 1984) but the site of action has been determined only for a staphylococcin (Morriss et al., 1978) and for pyocins (Morse et al., 1980).

In earlier work (Beaudet et al., 1982) we purified a gonococcal growth inhibitor produced by a strain of Staphylococcus haemolyticus isolated from the urogenital flora. This inhibitor is a lipid-associated protein, in which the protein moiety is responsible for the activity. The protein is composed of high mol. wt aggregates formed by small peptides of mol. wt c. $2.5 \times 10^{3}$ (Frenette et al., 1984). Biological characterisation showed that this inhibitor has a broad haemolytic spectrum and has some properties in common with $S$. aureus $\delta$ lysin (Frenette et al., 1984). The purpose of this study was to elucidate the site of action of this inhibitor on the gonococcal cell.

Received 3 Aug. 1987; revised version accepted 28 Oct. 1987.

* Requests for reprints should be addressed to Prof. R. Beaudet.

\section{Materials and methods}

\section{Bacterial strains}

S. haemolyticus strain no. 7, isolated from the urogenital flora (Bisaillon et al., 1981b), was used for the production of the inhibitor. $N$. gonorrhoeae strain G-10 (Bisaillon et al., 1981a) was used as the target organism for the inhibitor. All strains were kept lyophilised or as frozen suspensions at $-80^{\circ} \mathrm{C}$.

\section{Culture medium}

The gonococcal strain was grown on GC agar base (Gibco Diagnostics, Madison, WI, USA) enriched with CVA $1 \%$ (Gibco) and lysed horse blood $1.5 \%$, at $37^{\circ} \mathrm{C}$ in an atmosphere containing $\mathrm{CO}_{2} 5 \%$ with $70 \%$ relative humidity.

\section{Production and purification of the gonococcal inhibitor}

The inhibitor was produced and purified as previously described (Beaudet et al., 1982). Production was on semisolid Brain-Heart Infusion (BHI) Medium (Difco Laboratories) which had supported a 24-h growth of $S$. haemolyticus strain no. 7 at $37^{\circ} \mathrm{C}$. The inhibitory substance was purified by methanol extraction, acetone fractionation and chromatography on Ultrogel AcA54. The quantitative determination of the anti-gonococcal activity has already been described (Beaudet et al., 1982). The dilution of the preparation that caused a $50 \%$ decrease in the optical density (OD) of a gonococcal liquid culture, with respect to the control (without inhibitor), was taken to be the amount of arbitrary units (A.U.)/ml. 


\section{Effect of the inhibitor on gonococcal cells}

The effect of the inhibitor on growing gonococcal cells was determined by inoculating BHI medium containing inhibitor $(20$ A.U. $/ \mathrm{ml})$ with $N$. gonorrhoeae G-10 to obtain $5 \times 10^{7} \mathrm{cfu} / \mathrm{ml}$. Cultures were incubated at $37^{\circ} \mathrm{C}$ in $\mathrm{CO}_{2} 5 \%$ in a "Psychrotherm" incubator (New Brunswick Scientific Co., NJ, USA). A control culture without the inhibitor was also included. Viable counts and the OD at $540 \mathrm{~nm}$ of the cultures were determined every hour for $6 \mathrm{~h}$. The procedure to determine the effect of the inhibitor on resting cells was similar to the one previously described for growing cells except that BHI

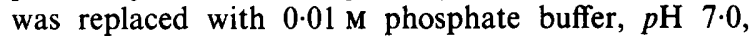
containing Proteose Peptone No. 3 (Difco) $1 \%$ and $\mathrm{NaCl}$ $0.85 \%$ (PPS). Each experiment was repeated four times and similar results were obtained.

\section{Effect of the inhibitor on gonococcal spheroplasts}

Gonococcal osmotic-sensitive cells were prepared by a modification of Kaback's method (Kaback, 1971). Cells grown in BHI medium were harvested in mid-exponential phase of growth, centrifuged, washed twice in $0.01 \mathrm{M}$ Tris- $\mathrm{HCl}$ buffer, $p \mathrm{H} \mathrm{8} \cdot 0$, containing PPS and resuspended in a small volume of $0.03 \mathrm{M}$ Tris- $\mathrm{HCl}$ buffer, $p \mathrm{H} 8.0$, containing Proteose Peptone No. $31 \%, \mathrm{NaCl} 0.85 \%$ and sucrose $30 \%$ (PPSS) to obtain a high density population. A volume of $0 \cdot 1 \mathrm{M} \mathrm{Na}{ }_{2}$ EDTA corresponding to one tenth of the final volume of the cell suspension, and solid lysozyme (grade 1; Sigma) to a final concentration of $100 \mu \mathrm{g} / \mathrm{ml}$, were added to the cell suspension. The cell suspension was incubated at room temperature for 30 $\min$.

The resulting spheroplasts were dispensed in tubes and incubated at $37^{\circ} \mathrm{C}, 24^{\circ} \mathrm{C}$ or $4^{\circ} \mathrm{C}$ with various concentrations of inhibitor or with Triton X-100 $35 \mu \mathrm{g} / \mathrm{ml}$ as a control to show maximal lysis. The OD of the suspensions was monitored at $540 \mathrm{~nm}$ at different time intervals for $2 \mathrm{~h}$. Each experiment was repeated three times and similar results were obtained.

\section{Effect of the inhibitor on the release of radioactive cytoplasmic material by gonococcal cells}

Gonococcal cells from an 18-h culture in Neisseria Chemically Defined Medium (Gibco) were harvested by centrifugation $\left(10000 \mathrm{~g}, 30 \mathrm{~min}, 4^{\circ} \mathrm{C}\right)$ and incubated in the same medium with uniformly labelled ${ }^{14} \mathrm{C}$ glucose (NEN, $1 \mu \mathrm{Ci} / \mathrm{ml}$ ), for $1.5 \mathrm{~h}$ at $37^{\circ} \mathrm{C}$ in $\mathrm{CO}_{2} 5 \%$ with agitation at $200 \mathrm{rpm}$. Cells were then centrifuged, washed twice and resuspended in $0.01 \mathrm{M}$ phosphate buffer, $p \mathrm{H}$ 7.0 containing PPSS. The suspensions were incubated at $37^{\circ} \mathrm{C}, 24^{\circ} \mathrm{C}$ or $4^{\circ} \mathrm{C}$ with various concentrations of inhibitor or with Triton X-100 $150 \mu \mathrm{g} / \mathrm{ml}$ as a control for maximal release of radioactive cytoplasmic material. At different time intervals samples of the suspensions were centrifuged at $15000 \mathrm{~g}$ for $8 \mathrm{~min}$ and the radioactivity of the supernates was measured with Bray's solution as scintillator.

\section{Electronmicroscopy}

Gonococcal cells from an 18-h culture on GC Agar Base (Gibco) enriched with CVA (Gibco) $1 \% \mathrm{v} / \mathrm{v}$ and lysed horse blood $1.5 \% \mathrm{v} / \mathrm{v}$ were centrifuged, washed and resuspended in PPSS. The inhibitor was added to the suspensions to a final concentration of $20 \mathrm{~A} . \mathrm{U} . / \mathrm{ml}$ and the suspensions were incubated at $4^{\circ} \mathrm{C}$ for $2 \mathrm{~h}$. The cells were centrifuged, washed in PPSS and fixed in glutaraldehyde $2.5 \%$ and osmic acid $2 \%$. The cells were then embedded in Vestopal W, cut in ultra-thin sections and stained with uranyl acetate $5 \%$ followed by lead citrate and examined in a Philips EM 300 electronmicroscope.

\section{Results}

The effect of the inhibitor produced by $S$. haemolyticus strain no. 7 on growing gonococcal cells is illustrated in fig. 1. The inhibitor caused a decrease in viable counts during the first $3 \mathrm{~h}$ of incubation from $5.6 \times 10^{7}$ to $7.7 \times 10^{5} \mathrm{cfu} / \mathrm{ml}$. Viable counts then stabilised until the end of the observation period. The OD of the treated suspension remained stable for the first $2 \mathrm{~h}$ of incubation and then decreased very slowly for the following $4 \mathrm{~h}$. As expected, viable counts and OD of control cultures increased steadily over the incubation period.

The inhibitor was also active on resting gonococcal cells. A sharp decrease in viable counts $(6 \cdot 1 \times$ $10^{7}$ to $\left.1.4 \times 10^{5} \mathrm{cfu} / \mathrm{ml}\right)$ of the treated suspension was seen during the incubation period while viable counts of the control suspension remained stable. The OD of the suspension decreased slightly in the presence of the inhibitor but not in controls.

The inhibitor caused lysis of gonococcal spheroplasts as suggested by a decrease in the OD of the cell suspensions (table). The extent of the reduction of OD was proportional to the concentration of the inhibitor in the suspension; the two higher doses used (5 and 7.6 A.U./ml) caused a drop comparable to that observed with Triton $\mathrm{X}-100$. At $4^{\circ} \mathrm{C}$, the inhibitor was still active on gonococcal spheroplasts but the decreases in OD were less than those observed at higher temperatures. The action of Triton X-100 did not seem to be affected by variations of temperature.

At $37^{\circ} \mathrm{C}$ the inhibitor caused an almost linear release with time of the radioactive cytoplasmic material from gonococcal cells (fig. 2). The two higher concentrations of the inhibitor were as active as Triton X-100 after incubation for $2 \mathrm{~h}$. At $24^{\circ} \mathrm{C}$ and $4^{\circ} \mathrm{C}$, the inhibitor still caused release of radioactive cytoplasmic material but its action was weaker than that observed at $37^{\circ} \mathrm{C}$. Again, the action of the Triton X-100 did not seem to be modified by variations of temperature. 

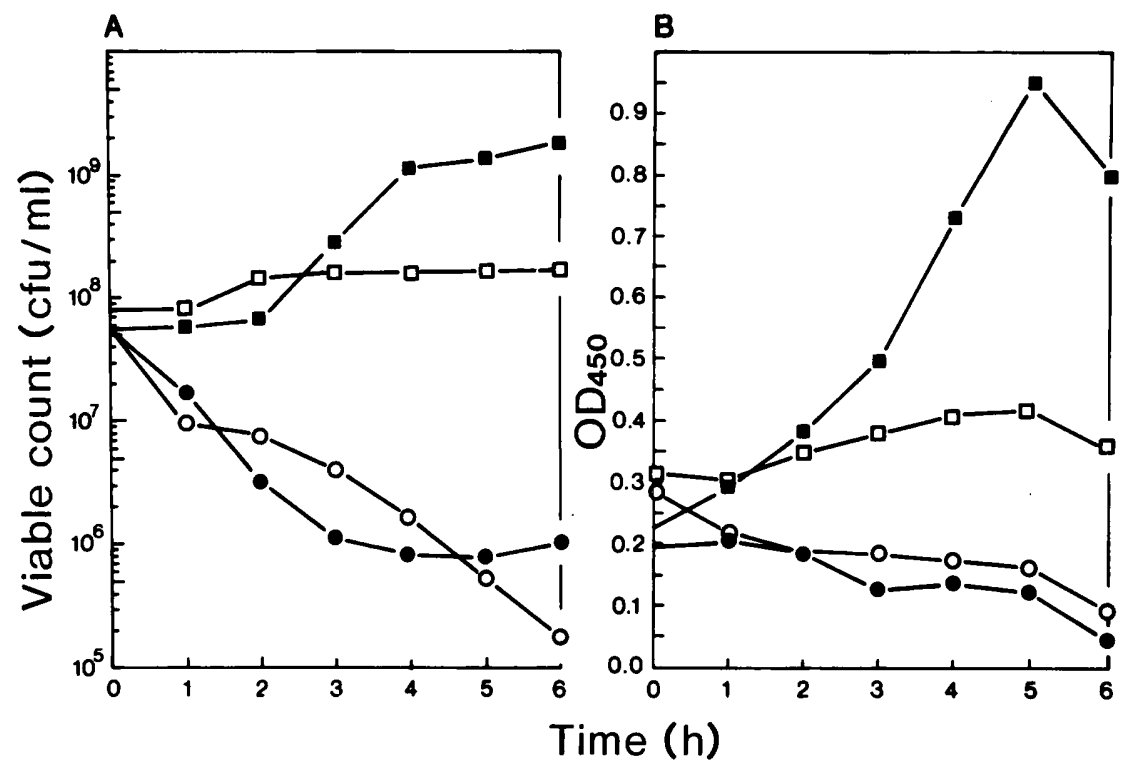

Fig. 1. Effect of the inhibitor $(20$ A.U./ml) on viable counts (A) and optical density (B) of growing (O) and resting (O) gonococcal cell suspensions; $\square, \square=$ control experiment without inhibitor.
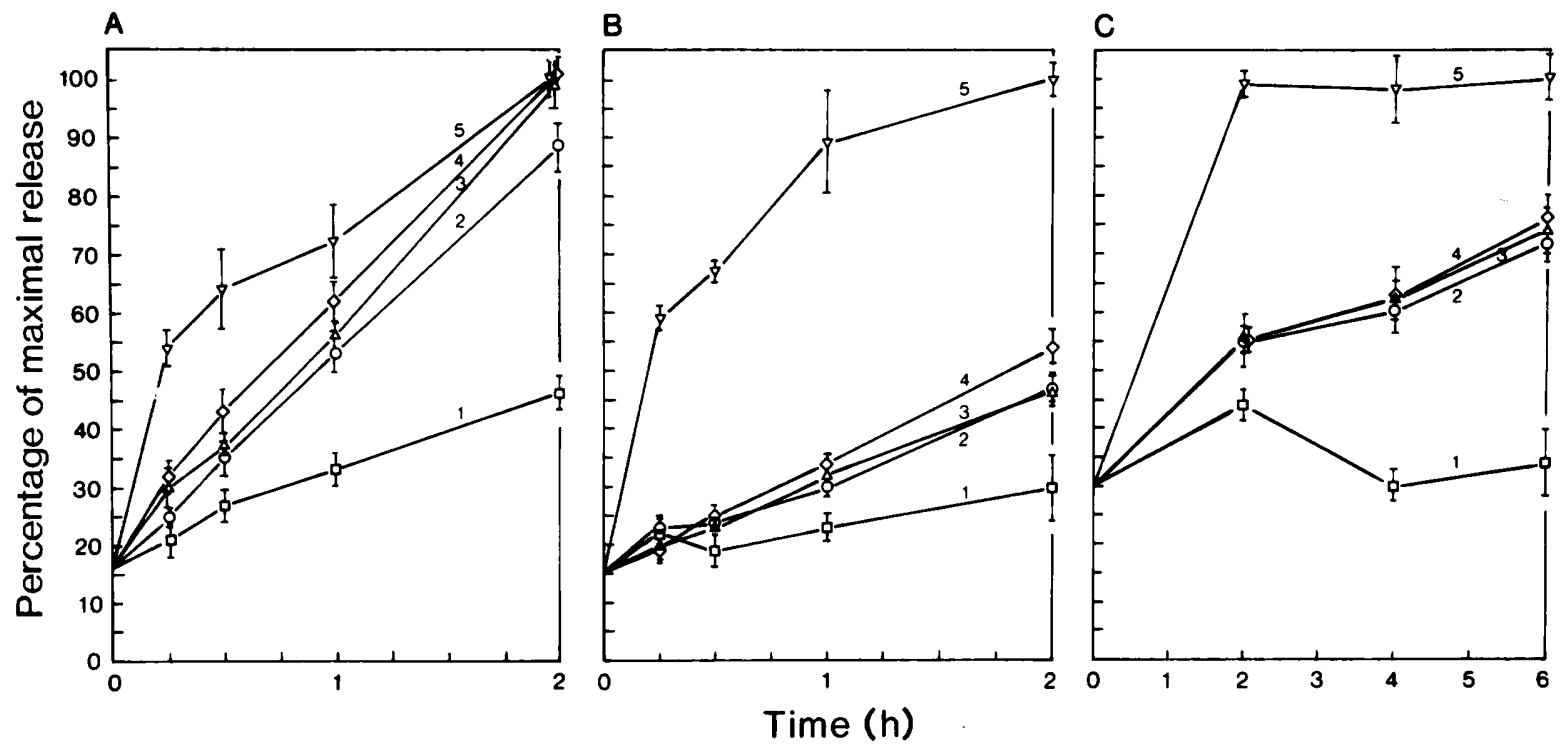

Fig. 2. Release of radioactive cytoplasmic material from gonococcal cells incubated in the presence of the inhibitor at $37^{\circ} \mathrm{C}(\mathrm{A}) 24^{\circ} \mathrm{C}$ (B) and $4^{\circ} \mathrm{C}(\mathrm{C})$. The concentrations of the inhibitor (A.U./mL) were: $0(1), 5(2), 10(3), 20$ (4). Triton X-100 (150 $\left.\mu \mathrm{g} / \mathrm{mL}\right)$ waș used as control for maximal lysis (5). Each value represents the mean of four experiments.

Electronmicrographs of the gonococcal cells incubated in the presence of the inhibitor showed that most of them were emptied of their cytoplasm (fig. 3). The cell walls seemed to remain intact and some diplococcoid "ghosts" were observed. Electronmicrographs of cells from the control group showed normal morphology.

\section{Discussion}

The site of action of many of the gonococcalinhibiting substances produced by bacteria from the urogenital flora has not been studied. According to Morriss et al. (1978) and Morse et al. (1980) the staphylococcin and the pyocin they described, 
Table. Effect of the inhibitor on gonococcal spheroplasts

\begin{tabular}{c|ccc}
\hline \multirow{2}{*}{$\begin{array}{c}\text { Inhibitor } \\
\text { concentration } \\
\text { (A.U./ml) }\end{array}$} & \multicolumn{3}{|c}{ Percentage reduction of OD at $540 \mathrm{~nm}^{*}$ at } \\
\cline { 2 - 4 } & $4^{\circ} \mathrm{C}$ & $24^{\circ} \mathrm{C}$ & $37^{\circ} \mathrm{C}$ \\
\hline 0 & 0 & 0 & 0 \\
$0 \cdot 3$ & 7.4 & $23 \cdot 2$ & 24.6 \\
0.6 & 10.7 & 35.7 & 36.1 \\
$1 \cdot 2$ & $15 \cdot 7$ & 46.4 & 47.6 \\
2.5 & 22.3 & 50.0 & 51.6 \\
5.0 & 30.6 & 58.9 & 60.7 \\
7.6 & 38.9 & 64.3 & 63.9 \\
Triton X-100† & 73.6 & 67.9 & 59.0 \\
\hline
\end{tabular}

* Gonococcal spheroplasts were incubated in the presence of inhibitor for $2 \mathrm{~h}$ and percentage reductions were calculated by comparison with OD of spheroplasts incubated without inhibitor under the same conditions.

$\dagger$ Triton X-100 $(35 \mu \mathrm{g} / \mathrm{ml})$ was used as a control for maximal lysis.

respectively, act on the cytoplasmic membrane of gonococci. The inhibitor produced by $S$. haemolyticus was active on growing and resting gonococcal cells, suggesting that this substance acts on a cell structure of the gonococcus and does not require an active metabolism (Russel et al., 1973). The OD of growing and resting suspensions of gonococci was only slightly reduced in the presence of the inhibitor but this does suggest that there could be some effect on the cell wall. However, it cannot be assumed that the inhibitor is directly responsible for this effect since autolysis is common in gonococcal cells suspended in a medium unable to maintain growth (Wegener et al., 1977). The inhibiting conditions might favour autolysis and further work on peptidoglycan hydrolysis is necessary to clarify this.

The inhibitor was also active on gonococcal spheroplasts. At $37^{\circ} \mathrm{C}$ and $24^{\circ} \mathrm{C}$ lysis was apparent at concentrations as low as $0.3 \mathrm{~A} . \mathrm{U} . / \mathrm{ml}$, which corresponded to 67 times less than that used on growing and resting cells. To show the release of cytoplasmic material caused by the antigonococcal substance, ${ }^{14} \mathrm{C}$-glucose was used to create a pool of radioactive material in the gonococcal cytoplasm. Morse and Bartenstein (1974) have shown that glucose is used by gonococci as the main carbon source; therefore, in our experiments, the radioactivity would be expected to become distributed in all cell components, particularly the cytoplasm. The inhibitor caused the release of radioactive cytoplasmic material from the gonococci. At $37^{\circ} \mathrm{C}$, doses of 10 and 20 A.U./ml caused a release equivalent to that observed with Triton $X-100$ but at $24^{\circ} \mathrm{C}$ and $4^{\circ} \mathrm{C}$ release was much reduced. These results, and those obtained with the spheroplasts, suggest that the site of action of this substance is the cytoplasmic membrane.

The inhibitor was already shown to have some properties similar to those of the $S$. aureus $\delta$ lysin (Frenette et al., 1984). Both substances have similar haemolytic spectra against erythrocytes of different animal species and both disrupt tissue culture cells and are inhibited by phosphatidylcholine. However, the observed effect of temperature on the activity of the gonococcal inhibitor is not shared by the $\delta$ lysin; Thelestam et al. (1973) and Kapral (1976) have shown the action of $\delta$ lysin on human fibroblast and human erythrocytes to be temperature independent.
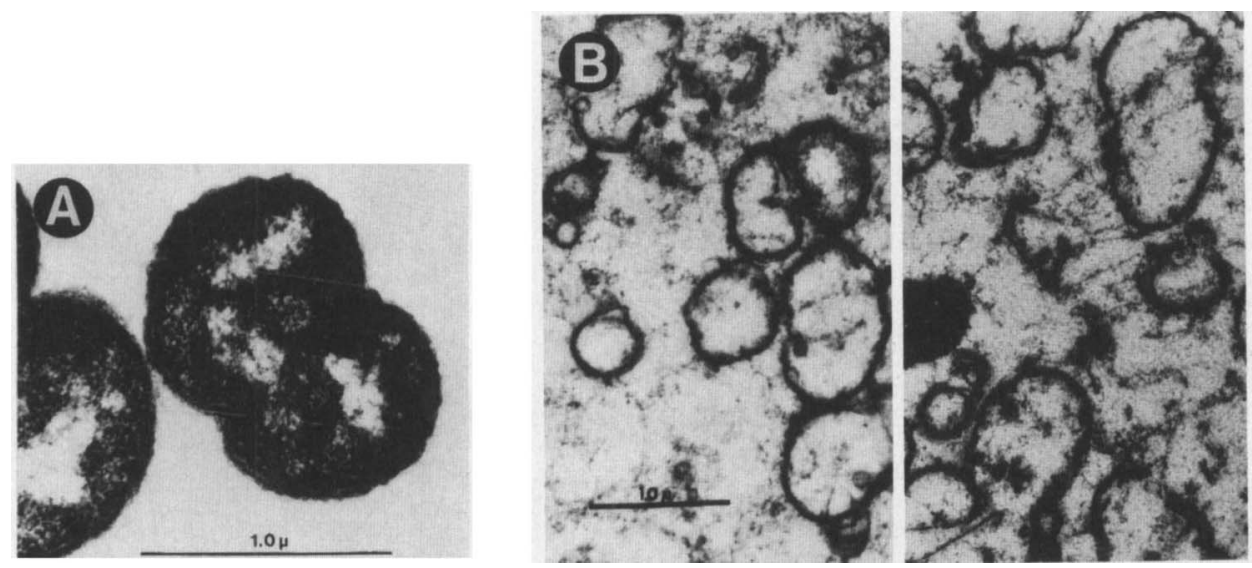

Fig. 3. Electronmicrographs of normal gonococcal cells $(A)(\times 36000)$ and gonococcal cells incubated in presence of the inhibitor $(20 \mathrm{~A} . \mathrm{U} . / \mathrm{ml})$ for $2 \mathrm{~h}$ at $4^{\circ} \mathrm{C}(\mathrm{B})(\times 20100)$. 
Electronmicrographs of gonococcal cells treated with the inhibitor showed these cells were emptied of their cytoplasm. There was no detectable ultrastructural damage to the cell envelope. Clawson and Dajani (1970) observed similar "ghost" formation with streptococcal cells treated with a bactericidal substance produced by $S$. aureus. This substance is different from the gonococcal inhibitor on the basis of its antibacterial spectrum and chemical properties.

Our results suggest that the inhibitor is acting on the cytoplasmic membrane of the gonococcus causing cytoplasmic leakage that eventually leads to cell death. We believe that the substance does not interfere with the cell wall or its synthesis, even though the OD of treated cell suspensions was slightly reduced in its presence. These results are in accord with the reported haemolytic activity of the inhibitor (Frenette et al., 1984) and suggest that this substance has high membranophilic properties which are not specific to a membrane type.

\section{REFERENCES}

Beaudet R, Bisaillon J-G, Saheb S A, Sylvestre M 1982 Production, purification and preliminary characterization of a gonococcal growth inhibitor produced by a coagulasenegative Staphylococcus isolated from the urogenital flora. Antimicrobial Agents and Chemotherapy 22:277-283.

Bisaillon J-G, Beaudet R, Lafond L, Saheb S A, Sylvestre M $1981 a$ Antigonococcal and antibacterial spectra of some bacterial isolates of the urogenital flora. Revue Canadienne de Biologie 40:215-217.

Bisaillon J-G, Beaudet R, Saheb S A, Morisset R $1981 b$ Interference of Neisseria gonorrhoeae growth by aerobic bacterial representatives of the urogenital flora. Revue Canadienne de Biologie 39: 201-208.

Clawson C C, Dajani A S 1970 Effect of bactericidal substance from Staphylococcus aureus on group A streptococci. II. Structural alterations. Infection and Immunity 1:491-498.

Dajani A S, Tom M C, Law D J 1976 Viridins, bacteriocins of alpha-hemolytic streptococci: isolation, characterization and partial purification. Antimicrobial Agents and Chemotherapy 9:81-88.

Dubreuil D, Bisaillon J-G, Beaudet R 1984 Inhibition of Neisseria gonorrhoeae growth due to hydrogen peroxide production by urogenital streptococci. Microbios 39:159167.

Frenette M, Beaudet R, Bisaillon J-G, Sylvestre M, Portelance V 1984 Chemical and biological characterization of a gonococcal growth inhibitor produced by Staphylococcus haemolyticus isolated from the urogenital flora. Infection and Immunity 46:340-345.

Ingraham L S 1978 Microbial inhibition of Neisseriagonorrhoeae. In: Brooks G F et al. (eds) Immunobiology of Neisseria gonorrhoeae. American Society for Microbiology, Washington, DC pp 350-355.

Kaback H R 1971 Bacterial membranes. In: Jakoby W B (ed) Methods in enzymology vol. 22, Enzyme purification and related techniques. Academic Press, New York, pp 99-120.
Although the in-vivo activity of the inhibitor against $N$. gonorrhoeae in guinea pig subcutaneous chambers has already been shown (Frenette $e t$ al., 1984), secretion has not been demonstrated in vivo and the role of this substance in resistance to gonorrhoea has not been established. The absence of an animal model reproducing the complexity of the urogenital tract, with the normal urogenital flora and physiological conditions of the host, including the vaginal secretions, immunity and the menstrual cycle, make this sort of study very difficult. This substance could be an interesting tool to study the structure and function of membranes; however, further work is necessary to determine the precise mechanism of action of the inhibitor.

We thank Rita Alary and Louis Racine for excellent technical assistance. The work was supported by Institut ArmandFrappier, a grant from the Medical Research Council of Canada and a "Bourse de stagiaire de recherche"(M.F.) given by "Fonds de la recherche en santé du Québec".

Kapral F A 1976 Effect of fatty acids on Staphylococcus aureus delta-toxin hemolytic activity. Infection and Immunity 13: 114-119.

Kaye D, Levison M E 1977 In vitro inhibition of growth of Neisseria gonorrhoeae by genital microorganisms. Sexually Transmitted Disease 4: 1-3.

Kraus S J, Ellison N 1974 Resistance to gonorrhea possibly mediated by bacterial interference. Applied Microbiology 27: 1014-1016.

Kraus S J, Geller R C, Perkins G H, Rhoden D L 1976 Interference of Neisseria gonorrhoeae growth by other bacterial species. Journal of Clinical Microbiology 4:288295.

Morin A, Saheb S A, Bisaillon J-G, Beaudet R, Sylvestre M 1980 In-vitro inhibition of Neisseria gonorrhoeae growth by strict anaerobes. Infection and Immunity 28: 766-770.

Morin A, Bisaillon J-G, Beaudet R, Sylvestre M, Saheb S A, Leduc D 1984 Preliminary characterization of inhibitors of Neisseria gonorrhoeae produced in vitro by Eubacterium limosum. Canadian Journal of Microbiology 30:251-259.

Morriss D M, Lawson J W, Rogolsky M 1978 Effect of a staphylococcin on Neisseria gonorrhoeae. Antimicrobial Agents and Chemotherapy $14: 218-223$.

Morse S A, Bartenstein L 1974 Factors affecting autolysis of Neisseria gonorrhoeae. Proceedings of the Society for Experimental Biology and Medicine 145: 1418-1421.

Morse S A, Vaughan P, Johnson D, Inglewski B H 1976 Inhibition of Neisseria gonorrhoeae by a bacteriocin from Pseudomonas aeruginosa. Antimicrobial Agents and Chemotheraphy $10: 354-362$.

Morse S A, Jones B V, Lysko P G 1980 Pyocin inhibition of Neisseria gonorrhoeae: mechanism of action. Antimicrobial Agents and Chemotherapy 18:416-423.

Rogolski M, Wiley B B 1977 Production and properties of a staphylococcin genetically controlled by a staphylococcal plasmid for exfoliative toxin synthesis. Infection and Immunity 15: 726-732.

Russel A D, Morriss A, Allwood M C 1973 Methods for 
assessing damage to bacteria induced by chemical and physical agents. In : Norris J R, Ribbons D W (eds) Methods in microbiology, vol. 8. Academic Press, London, pp 95182.

Simpson D M, Davis C P 1979 Properties of a gonococcal inhibitor produced by Escherichia coli. Journal of General Microbiology 115:471-477.

Thelestam M, Mollby R, Wadstrom T 1973 Effects of staphylo- coccal alpha-, beta-, delta- and gamma-hemolysins on human diploid fibroblasts and HeLa cells: evaluation of a new quantitative assay for measuring cell damage. Infection and Immunity 8:938-946.

Wegener W S, Hebeler B H, Morse S A 1977 Cell envelope of Neisseria gonorrhoeae: relationship between autolysis in buffer and the hydrolysis of peptidoglycan. Infection and Immunity 18:210-219. 